УДК 340.12

DOI https://doi.org/10.32837/pyuv.v1i3(28).315

B. І. Сировацький кандидат юридичних наук, адвокат

\title{
ТЕМПОРАЛЬНО-ПРОСТОРОВІ КООРДИНАТИ ДЕРЖАВОТВОРЕННЯ І ПРАВОТВОРЕННЯ (ПРАВОВА ОСВІЧЕНІСТЬ ГРОМАДЯН)
}

Усі процеси, що відбуваються в державі, мають прямий чи опосередкований вплив на громадян. Іноді здається, що деякі нововведення, рішення чи процес впливають лише на незначну частину населення, окрему категорію чи групу людей, яких вони стосуються безпосередньо. Це стосується локальних нормативно-правових актів, дія яких поширюється на певну територію чи групу осіб. Однак дія законодавчих актів поширюється на всю територію країни та населення, їхні вимоги повинні виконувати всі без винятку. Дотримання встановлених законів громадянами, з одного боку, та державою щодо людини, із другого - запорука стабільності в державі. Завдяки цьому формується баланс, що допомагає утримувати державу на певному рівні у правовій системі показників, наближаючи або віддаляючи її від правової держави та громадянського суспільства.

По-перше, щоби громадяни дотримувалися законів, вони передусім повинні мати можливість ознайомитися з ними; по-друге, іноді людині необхідна консультація-роз'яснення для вчинення або уникнення здійснення якихось дій (а вартість професійної консультації юриста не кожний може оплатити); людина має бути впевнена, що держава, через компетентні органи й уповноважених законом осіб, у разі необхідності в найкоротші терміни відновить іiї порушене право та покарає порушників відповідно до закону.

Одним із завдань держави є гарантування дотримання прав і свобод людини. Кожний має право звернутися до компетентних органів для відновлення свого порушеного права. Проте, як відомо, простіше попередити певну подію, ніж ліквідувати її негативні наслідки. Саме тому одним із пріоритетних напрямів роботи у правовій сфері $\epsilon$ підвищення загального рівня правової освіченості громадян. Завдяки цьому чимала кількість людей отримують правові знання, які допоможуть їм уникнути вчинення дій, що суперечать закону, та не допустити порушення особистих прав і свобод, а також знати правові механізми відновлення свого порушеного права. Н. Оніщенко зазначає: «Правова освіта може розглядатися як система виховних і навчальних дій, спрямованих на створення умов для формування: поваги до права; власних уявлень і настанов, заснованих на сучасних правових цінностях суспільства; концепцій, достат- ніх для захисту прав, свобод і законних інтересів особи та правомірної реалізації її громадянської позиції» [1, с. 35-36]. Тобто, маючи певний рівень правової освіти, людина зможе не лише захистити свої права та свободи, а й уникнути багатьох помилок у правовому полі, через які згодом доведеться звертатися по допомогу до професійних юристів чи правоохоронних органів.

Сьогодні в даному напрямі робиться чимало: це і наявність уроків правознавства у школах, професійно-технічних закладах освіти, право викладається як навчальна дисципліна у ЗВО неправового спрямування, існують центри надання безоплатної юридичної допомоги, юридичні клініки при навчальних закладах відповідного напряму, у засобах масової інформації публікують численні статті на юридичну тематику з роз'ясненнями спеціалістів конкретного профілю. Однак, попри це, сьогодні значна частина населення все ще не може не лише себе захистити, а й елементарно не знає своїх прав. «Сучасний розвиток правової освіти в Україні повинен орієнтуватися на формування в наших громадян нових цінностей демократії, реальної правової та соціальної держави з повагою до національної правової культури, яка відповідає загальнолюдським цінностям і прагненням, сприяє всебічному забезпеченню прав і свобод особистості, розквіту сучасного громадянського суспільства в Україні» [2, с. 44].

На нашу думку, найбільш ефективним способом впливу на правову освіченість громадян $€$ продумана системна діяльність держави у сфері державотворення та правотворення, яка дає змогу людині відчути себе цінною для держави та своєю поведінкою показати важливість цінностей громадянського суспільства та правової держави для себе.

Процеси державотворення i правотворення є нероздільними та відбуваються паралельно. Із розвитком держави розвивається і право, оскільки з'являється необхідність у правовому регулюванні життєдіяльності держави. На їх розвиток впливають чимало чинників, які ми умовно розділили на чотири групи: 1) телпоральні - це група чинників, які визначають часові межі явищ, процесів і подій; швидкість перебігу подій у часі. Жодне явище, процес чи подія не виникають самі собою, а є своєрідним ланцюжком, між елементами якого можна віднайти причинно-наслідковий 
зв'язок. Зародження, формування та тривалість їхнього (процесів, явищ, подій) існування визначаються умовами життєдіяльності суспільства та його потребами в конкретний період, проміжок часу. Темпоральність - це «часова сутність явищ, породжена динамікою їх особливого руху, у відмінності від тих часових характеристик, які визначаються відношенням руху даного явища до історичних, астрономічних, біологічних, фізичних та інших часових координат» [3, с. 298]. Тобто, виходячи з даного визначення, темпоральність є радше явищем синхронним, ніж діахронним. Певні державотворчі процеси одночасні з деякими правотворчими процесами, завдяки чому можна отримати швидку реакцію держави (у вигляді нормативно-правових актів) на «запити» та потреби суспільства в конкретний період часу. Завдяки групі темпоральних чинників ми можемо віднайти певні координати державотворення та правотворення в межах часового виміру, зокрема збіг / незбіг періодів зародження, функціонування чи занепаду певних державно-правових явищ, виявити причини занепаду одних і тривалого функціонування тих чи інших процесів, явищ, спрогнозувати можливість розвитку певних процесів та, за необхідності, уникнути їх або ж мінімізувати негативний вплив та його наслідки на життєдіяльність суспільства; 2) просторові - сукупність чинників, які окреслюють просторові межі функціонування державотворчих та правотворчих процесів і явищ. Часто простір окреслюють як певне вмістилище предметів та подій. Як одна з координат державотворення та правотворення простір являє собою сферу поширення та дії санкціонованих державою моделей поведінки. В. Кравчук визначає правовий простір як «цілісний комплекс правових явищ, дій та подій, взаємозв'язків і відносин, обумовлений об'єктивними закономірностями розвитку людства, усвідомлений і постійно відтворюваний людьми та їх об'єднаннями, що використовується ними для досягнення своїх цілей, реалізації домагань» [4, с. 31]. Тобто простір є цілісністю, що об'єднує в систему взаємопов'язані явища, події та дії, виникнення і функціонування яких зумовлене усвідомленими потребами людства; 3) соціальні - комплекс чинників, які зумовлені розвитком людини та необхідністю у зв'язку із цим розвитку держави та права для забезпечення можливостей гідного життя та гармонійного розвитку особистості. Зміни в соціальній сфері життя людей зумовлюють необхідність певних змін чи нововведень у державно-правовій сфері. Саме людина, шукаючи своє місце у світі, замислюючись над питаннями якості свого життя, усвідомлюючи необхідність залишення певної спадщини прийдешнім поколінням, виступає рушієм розвитку суспільства та держави, прагнучи постійного вдосконалення вже існуючих умов життя та створення нових форм співіснування і взаємодії людей. Таким чином виникають нові види соціальних відносин і з'являється необхідність їх правового регулювання для утримання балансу в державі. «<...> Правове регулювання $<$...> - це система дій та операцій, які здійснюються органами державної влади у встановлених процесуальних формах за допомогою певних методів та з використанням при цьому юридичних засобів, спрямованих на встановлення і реалізацію певних моделей суспільного розвитку» [5, с. 22]. Загалом більшість людей чітко уявляють умови, у яких вони хотіли б жити та взаємодіяти з іншими людьми і суспільством. Такі уявлення трансформуються в певні моделі поведінки, прийняті суспільством або ж відкинуті як такі, що суперечать нормам моралі та права. Держава надає оцінку таким моделям, санкціонуючи або ж забороняючи ïх шляхом видання нормативно-правових актів. А соціум, у свою чергу, також реагує на нововведення і наділений усіма законними правами для того, щоб домогтися скасування законодавчих норм та владних приписів, які, на його думку, певним чином обмежують права та свободи людини і громадянина. Так і відбувається «комунікація» у межах систем «людина - держава», «людина - право»; 4) перспективні - множинність існуючих чинників, які в майбутньому можуть суттєво впливати на процеси державотворення i правотворення шляхом зміни їхніх істотних ознак, накопичення негативних елементів, що в подальшому знецінить даний процес чи явище або ж призведе до його деградації і занепаду. 3 метою попередження таких проявів необхідно проводити перспективні дослідження, що мають на меті з'ясувати, чи доцільним є впровадження для довготривалого функціонування того чи іншого процесу, допомогти виявити його слабкі та сильні сторони з метою проведення певного коригування, урахувати громадську думку та готовність населення до сприйняття пропонованого нововведення. Такий комплекс заходів допоможе уникнути недоцільного використання людських і матеріальних ресурсів, знизити ризики, пов'язані із соціальним невдоволенням та несприйняттям тих чи інших явищ або процесів; не допустити збільшення кількості правопорушень, які можуть спричинити нові деструкційні явища та процеси в державотворенні та правотворенні.

«Державотворення» та «правотворення» взаємопов'язані поняття. Із розвитком держави виникає необхідність у вдосконаленні права як системи регулювання відносин у системах «людина - людина» та «людина - держава». Розвиток права, у свою чергу, стимулює розвиток держави. «Розуміння місця та ролі держави у правотворчій діяльності розкривається через: зміст діяльності органів держави, що наділені правотворчими 
повноваженнями; гарантування державою авторитетності та загальнообов'язковості актів правотворчості, що в подальшому становлять систему законодавства держави; функціональне призначення держави у сфері правотворчості як окремого напряму створення та подальшого вдосконалення законодавчої бази держави; розуміння держави як ключового фактора правотворчості, яка визначає об'єктивну необхідність зміни правового регулювання; характеристику монопольного значення держави у формуванні права як на національному, так і на міжнародному рівні, де в першому випадку правотворча діяльність є одноосібною, а в другому - колегіальною» [6, с. 159]. Тобто передусім держава відповідальна перед людиною за дотримання іï прав та свобод шляхом своєї панівної ролі у процесі правотворчості. Держава «вказує» людині, як необхідно поводитися, щоб отримати певні блага, а за які проступки вона буде покарана, зазнаючи певних обмежень своїх прав і свобод.

Однак для того, щоб зберігався баланс сил у системі «людина - держава», людина, окрім механічного дотримання законів та інших нормативно-правових актів, виданих державною владою, повинна мати певний рівень знань у правовій сфері. Правова освіченість допоможе людині найперше знати свої права й обов'язки; вимагати виконання її прав та дотримання свобод; уникати вчинків, що слугуватимуть підставою для застосування до людини державного примусу; вимагати відновлення свого порушеного права; стати повноцінним суб'єктом державотворення та правотворення, який готовий ухвалювати рішення на основі власної усвідомленої системи моральних і правових цінностей, брати відповідальність за свої вчинки та їхні наслідки.

Безпосередній вплив на правову освіченість громадян мають правова ідеологія, правова культура, правове виховання. Ці три складових частини формує та санкціонує держава. Власне рівень правової освіченості громадян залежить від того, наскільки держава зацікавлена в цьому. Так, у розвинених демократичних державах відсоток громадян, які мають достатній рівень правової освіченості, значно вищий, ніж у державах, де керманичами є авторитарні лідери. Саме держава має культивувати правову ідеологію, створювати умови для їі поширення та формувати основу для сприйняття суспільством. Шляхом пропагування правової ідеології держава не лише формально впливає на людину, а й формує її правосвідомість, певним чином виховує особистість, яка свідомо дотримується правомірної поведінки, на основі власної системи моральних і правових цінностей зможе виробити особисті критерії оцінки вчинків та поведінки людей, певним чином орієнтується в політико-правових питаннях та виступає суб’єктом правотворення і державотворення. «Правова ідеологія, що культивується в державі, впливає на їі цілісність, моральність, подолання проявів правового нігілізму, позначається на зовнішній політиці держави, можливостях пошуку консенсусу та компромісу тощо» [7, с. 21]. На думку Т. Тарахонич, завдяки державній правовій ідеології можна впливати на рівень моральності людей, знизити рівень правового нігілізму серед населення. Ми цілком поділяємо цю думку, адже разом зі зниженням рівня правового нігілізму можна і подолати низку проблем, пов'язаних із застосуванням державного примусу. Так, якщо значна частина суспільства знає та поділяє правову ідеологію, то тим самим і свідомо дотримується правомірної поведінки, поважає закон і державу, у якій проживає.

Наступною складовою частиною правової освіченості людини є правова культура. У процесі свого розвитку держава сформувала певну систему цінностей, які стосуються всіх сфер життя суспільства. Загалом усі цінності сформували культуру держави, вони стали народним надбанням та складовою частиною загальнолюдської культури. Уже на їх основі кожна людина сформувала свою власну систему цінностей і пріоритетів, яка грунтується на її особистих усвідомлених прагненнях, моральних настановах. Не є винятком і правова система, у якій сформувалася правова культура. «Рівень правової культури» та «рівень загальної культури» не є співвідносними поняттями. Іноді можна спостерігати випадки, коли держава має значні загальнокультурні надбання, які належать до світової культурної спадщини, однак рівень правової культури в такій державі надзвичайно низький: не дотримуються принципи права, доступ до правосуддя має незначна частина населення, яка належить до панівної верхівки, держава не виконує взятих на себе зобов' язань. «За рівнем правової культури можна визначити загальний стан правової системи суспільства, законодавства, діяльності судів, усіх правоохоронних органів, правосвідомості всього населення держави, що відображає рівень розвиненості права та правосвідомості, засвоєння правових цінностей, здійснення вимоги верховенства права» [8, с. 15].

Існує ситуація, коли закони та підзаконні нормативно-правові акти чітко та юридично грамотно визначають права та свободи громадян, встановлюють норми поведінки, однак у реальному житті вони не діють. Особливо часто така ситуація виникає у країнах, що роблять перші кроки на шляху до побудови правової держави та громадянського суспільства. Причиною цього найчастіше є свідомість людей; багатьох не влаштовує перехід на нові принципи та правила поведінки, хтось просто звик вчиняти так, а перебудовувати себе та свою поведінку не хоче, комусь просто байдуже, голов- 
не, щоб не зачіпали його особисто. Тут апелювати потрібно до свідомості людини.

Правова культура не є простим віддзеркаленням рівня розвитку права, виразником досконалості нормативно-правових актів. Вона розвивається разом із державою та суспільством і є відображенням правової дійсності, що показує ставлення населення до права, рівень його сприйняття й усвідомлене його дотримання. Розвиток держави сприяє розвитку та вдосконаленню всіх сфер суспільного життя. Так, у державах із чіткою правовою ідеологією та високим рівнем правового виховання рівень правової культури буде вищим, ніж у державах, де нехтуються основні права і свободи людини і громадянина. Це відбувається тому, що сама держава не зацікавлена в освічених громадянах, які знатимуть та будуть здатні захистити свої права і свободи, адже це може привести і до зміни самої влади.

Правове виховання є третьою складовою частиною правової освіченості людини. Найчастіше правове виховання трактують як діяльність держави (освітніх закладів різних рівнів, правоохоронних органів, установ та організацій, діяльність яких пов'язана з наданням населенню юридичних послуг), що спрямована на формування в людини комплексу правових знань. «Правове виховання це цілеспрямована, послідовна, систематична діяльність держави та органів влади, а також громадських об'єднань й організацій, які формують певну систему правових знань, вмінь, навиків, правового мислення, правових почуттів (почуття права, законності, почуття поваги до права і закону, до тих соціальних цінностей, які регулюються та охороняються правом та законодавством)» [9, с. 16]. Хоча таке трактування потребує розширення, що пов'язано 3 тим, що первинні правові знання та навички правомірної/неправомірної поведінки людина формує ще в ранньому дитинстві. Вона автоматично поводиться так, як поводяться люди, що її оточують. Якщо найближче оточення дитини допускає неправомірну поведінку, сповідує нігілізм щодо права та держави, то й дитина поводитиметься аналогічно. I навпаки, діти, які зростають у сім'ях, де пропагується повага до держави, а цінності права покладені в основу поведінки батьків, також поводитимуться правослухняно. Саме батьки повинні першими познайомити дитину з нормами поведінки вдома, у громадських місцях, із правилами дорожнього руху тощо. Найкращою ілюстрацією, прикладом до таких роз'яснень стане поведінка найближчих дитині людей.

Ще одним важливим аспектом є наявність бажання людини до самовдосконалення протягом життя, а в даному випадку - до сприйняття та засвоєння нових знань у правовій сфері. Це зумовлено насамперед стрімкими темпами розвитку суспільства і держави, отже, і необхідністю розвитку права як регулятора суспільних відносин. Основна вимога часу - людина має бути суб'єктом правотворення та державотворення. Повноцінним суб'єктом таких процесів може стати тільки людина, яка має власну систему морально-етичних і правових цінностей, усвідомлено вчиняє правомірно, відкрита до сприйняття нових знань.

Завдяки грунтовно продуманому та послідовному правовому вихованню можна: 1) сформувати повагу до права та держави; 2) виховати людину, яка свідомо ставитиметься до своїх прав і обов'язків; 3) вплинути на процес формування правової свідомості людини; 4) знизити рівень злочинності шляхом виховання негативного ставлення до будь-яких порушень закону; 5) вплинути на рівень правової освіченості громадян шляхом залучення до правового виховання якнайбільшої кількості людей; 6) знизити кількість випадків застосування державного примусу шляхом охоплення правомірною поведінкою значної частини населення; 7) розвантажити роботу державних органів і служб, посадових осіб, пов'язану з наданням інформації про права людини в тій чи іншій сфері (найбільше це стосується сфери соціального захисту населення).

Підсумовуючи, доцільно зазначити, що процеси державотворення та правотворення впливають на правову освіченість громадян, допомагаючи їм засвоїти правові знання, необхідні для захисту своїх прав і свобод, сформувати критерії для оцінки поведінки (як своєї, так і інших людей) відповідно до вимог права та моралі. Разом з отриманням таких знань людина проходить і процес правової соціалізації, під час якого оволодіває стандартами правомірної поведінки та правовими цінностями, водночас починає впливати на їх формування.

\section{Jimepamypa}

1. Оніщенко Н. Правова освіченість у контексті рівнів правової освіти. Віче. 2012. № 23. С. 35-37.

2. Іваній О. Правова освіта як засіб формування громадянського суспільства. Науковий вісник Міжнародного гуманітарного університету. Серія «Юриспруденція». 2016. № 22. С. 42-45.

3. Современная западная философия : словарь / сост. : В. Малахов, В.П. Филатов. Москва : Политиздат, $1991.414 \mathrm{c}$.

4. Кравчук В. Поняття правового простору: філософсько-правова інтерпретація. Актуальні проблеми держави і права. 2014. Вип. 74. С. 26-31.

5. Демків Р. Правове регулювання як юридичне явище: окремі аспекти розуміння. Науковий вісник Ужгородського національного університету. Серія «Право». 2015. Вип. 34. Т. 1. С. 19-23.

6. Дідич Т. Значення та роль держави в сфері правотворчої діяльності в сучасних умовах: постановка проблеми. Альманах права. 2012. Вип. 3. С. 156-160.

7. Тарахонич Т. Правова ідеологія як внутрішня детермінанта правового впливу. Jurnalul Juridic National: Teorie si Practica. 2016. Octombrie. C. 19-21. 
8. Сгоров О. Правова культура: поняття, елементи та рівні. Правничий вісник Університету «КРОК». 2011. Вип. 9. С. 13-18.

9. Коваленко Н. Сутність взаємозв'язку правової культури та правового виховання. Науковий вісник Ужгородського національного університету. Серія «Право». 2016. Вип. 38. Т. 1. С. 15-18.

\section{Анотація}

Сировацький В. I. Темпорально-просторові координати державотворення і правотворення (правова освіченість громадян). - Стаття.

У статті проведено філософсько-правовий аналіз темпорально-просторових координат державотворення і правотворення (правова освіченість громадян). Обгрунтовано, що дотримання встановлених законів громадянами, з одного боку, та державою щодо людини, із другого, є запорукою стабільності в державі. Завдяки цьому формується баланс, що допомагає утримувати державу на певному рівні у правовій системі показників, наближаючи або віддаляючи її від правової держави та громадянського суспільства. Отже, щоби громадяни дотримувалися законів, вони передусім повинні мати можливість ознайомитися 3 ними; по-друге, іноді людині необхідна консультація-роз'яснення для вчинення або уникнення здійснення певних дій (а вартість професійної консультації юриста не кожний може оплатити); людина має бути впевнена, що держава, через компетентні органи й уповноважених законом осіб, за необхідності, у найкоротші терміни відновить її порушене право та покарає порушників відповідно до закону. 3'ясовано, що одним із завдань держави є гарантування дотримання прав і свобод людини. Кожний має право звернутися до компетентних органів за відновленням свого порушеного права. Проте, як відомо, простіше попередити певну подію, ніж ліквідовувати її негативні наслідки. Саме тому одним із пріоритетних напрямів роботи у правовій сфері є підвищення загального рівня правової освіченості громадян. Завдяки цьому чимало людей отримують правові знання, які допоможуть їм уникнути вчинення дій, що суперечать закону, та не допустити порушення особистих прав свобод, а також знати правові механізми відновлення свого порушеного права. На основі проведеного аналізу доведено, що найбільш ефективним способом впливу на правову освіченість громадян $\epsilon$ продумана системна діяльність держави у сфері державотворення та правотворення, яка дає змогу людині відчути себе цінною для держави, своєю поведінкою показа- ти важливість цінностей громадянського суспільства та правової держави для себе.

Ключові слова: державотворення, правова ідеологія, правотворення, правова культура, правове виховання, держава, суспільство, людина, громадянин, примус, філософія права.

\section{Summary}

Syrovackyi V. I. Temporal-spatial coordinates of state formation and lawmaking (legal education of citizens). - Article.

The article deals with the philosophical and legal analysis of the temporal and spatial coordinates of state formation and lawmaking (legal education of citizens). It is substantiated that the observance of statutory laws by citizens on the one hand and the state against a person on the other is a guarantee of stability in the state. This creates a balance that helps to keep the state at a certain level in the legal system of indicators, bringing it closer or further away from the rule of law and civil society. Therefore, in order to be law-abiding, citizens must first have access to them; secondly, sometimes a person needs counseling and clarification to commit or avoid taking certain actions (and not everyone can pay the cost of a lawyer's professional advice); a person must be sure that the state, through the competent authorities and persons empowered by law, will restore its violated right and punish the violators in accordance with the law as soon as possible. It has been found that one of the tasks of the state is to guarantee respect for human rights and freedoms. Everyone has the right to apply to the competent authorities for the restoration of their infringed right. However, it is known that it is easier to prevent an event than to eliminate its negative consequences. That is why one of the priority areas of work in the legal sphere is to increase the general level of legal education of citizens. Due to this, a considerable number of people receive legal knowledge that will help them avoid committing acts contrary to the law, prevent violations of personal rights and freedoms, as well as know the legal mechanisms of restoration of their violated rights. Based on the analysis, it is proved that the most effective way of influencing the legal education of citizens is a thoughtful systematic activity of the state in the sphere of state formation and lawmaking, which allows a person to feel valuable for the state and his behavior to show the importance of the values of civil society and the rule of law for himself.

Key words: state formation, legal ideology, law making, legal culture, legal education, state, society, man, citizen, coercion, philosophy of law. 